\title{
O PARQUE MOSCOSO COMO ESPAÇO-MEMÓRIA DA CIDADE DE VITÓRIA: TRABALHANDO COM LEITURA DE IMAGENS
}

\section{THE MOSCOSO PARK AS MEMORY SPACE OF THE CITY OF VITORIA: WORKING WITH PICTURE READING}

\author{
Larissa Pinheiro ${ }^{1}$; Priscila Chisté ${ }^{2}$ \\ Instituto Federal do Espírito Santo \\ larissafma@gmail.com; priscilachiste.ufes@gmail.com
}

\begin{abstract}
Resumo
O objetivo deste artigo é apresentar o potencial educativo da cidade, tendo como enfoque a memória constituída no Parque Moscoso, localizado em Vitória/ES, através da leitura de imagem de suas fotografias. Para tanto, dentro da abordagem do materialismo históricodialético, trabalhamos com leitura de imagens com a finalidade de desvelar contradições sociais e compreender o Parque Moscoso como uma totalidade, mostrando que novos espaços de sociabilidade não foi apropriado por toda população, aprofundando a segregação socioespacial de uma cidade marcada por uma modernização excludente. Constatamos que experiências educativas nesse sentido são importantes para valorizarmos espaços das nossas cidades e ampliarmos as possibilidades do fazer pedagógico.
\end{abstract}

\section{Palavras-chave}

Educação na cidade. Memória. Educação não-formal. Imagens. Leitura de imagem.

\section{Abstract}

The objective of this article is to present the educational potential of the city, focusing on the memory constituted in Moscoso Park, located in Vitória/ES, by reading the image of its photographs. To do so, within the approach of historical-dialectical materialism, we work with reading images with the purpose of unveiling social contradictions and understanding the Moscoso Park as a totality, showing that new spaces of sociability were not appropriated by the entire population, deepening socio-spatial segregation of a city marked by an excluding modernization. We find that educational experiences in this sense are important to value spaces in our cities and expand the possibilities of pedagogical making.

\footnotetext{
${ }^{1}$ Aluna do Programa de Pós-Graduação em Ensino de Humanidades, IFES (Campus Vitória). Bolsista da Fundação de Amparo à Pesquisa e Inovação do Espírito Santo (FAPES).

2 Professora do Programa de Pós-Graduação em Ensino de Humanidades, IFES (Campus Vitória).
} 


\section{Keywords}

Education in the city. Memory. Non-formal education. Images. Picture reading.

\section{Introdução}

O presente artigo tem como objeto de investigação o Parque Moscoso, situado no município de Vitória, Espírito Santo, e suas interfaces com a educação, memória e cidade. 0 Parque Moscoso é o primeiro parque urbano da capital capixaba, construído em 1912, a partir de um olhar modernizante, onde todos os vestígios da cidade provinciana foram substituídos pelo projeto francês de urbanização que tinha como finalidade consolidar uma política urbana para repensar as cidades (SOUSA, 2012).

Observamos que ao se tratar do Parque Moscoso nos poucos materiais produzidos sobre ele, se verifica que a história é contada e recontada sem ou pouco problematizar os seus aspectos sociais, políticos, culturais e econômicos. Também não encontramos com facilidade materiais educativos que tratem de questões relacionadas aos espaços de nossa cidade. Nesse sentido, cabe a sistematização de tal recurso pedagógico para que os leitores conheçam um pouco mais sobre a história e a memória do Parque Moscoso de modo a identificarem as contradições sociais que surgem desse projeto urbano conduzido pelas elites locais.

A pesquisa foi desenvolvida tendo como suporte teórico o materialismo históricodialético que nos auxilia a compreender como opera o discurso e a linguagem que concebe um conhecimento que produz segmentação histórica. Na prática, auxilia o professor a identificar como a concepção hegemônica e totalitária imposta pela classe dominante, se reproduz em espaços institucionais formais, como por exemplo, na escola que como pretenso aparelho ideológico do Estado burguês pode promover alienação, na medida em que contribui para ocultar as contradições sociais (RODRIGUEZ, 2014).

A partir disso, compreendemos o Parque Moscoso como parte da memória da cidade de Vitória. Desse modo, o objetivo geral desta investigação que se apresenta sob forma reduzida neste artigo, é compreender através de uma perspectiva crítica as relações entre memória e cidade para propor material educativo, voltado para o estudo do Parque Moscoso. Contudo, discorreremos apenas sobre parte de tal investigação ressaltando aspectos relacionados com a possibilidade de compreender o Parque Moscoso de modo dialógico e polifônico, a partir do estudo de fotografias antigas tomadas desse espaço. 
Como forma de sistematizar o texto na primeira seção discorreremos de forma sintética a história do Parque Moscoso. Já na segunda seção apresentamos a ideia de educação na cidade como uma proposta educativa contra-hegemônica de diálogo entre a escola e a cidade. E, por fim, na terceira seção apresentamos a possibilidade de trabalhar com fotografias antigas do Parque Moscoso por meio de leitura de imagens, tendo como temática principal as paisagens do Parque Moscoso.

\section{Sobre o Parque Moscoso}

O parque foi construído em 1912, durante o governo Jerônimo Monteiro, em uma área chamada Lapa do Mangal (Figura 1), constituída por terrenos alagados pelas marés, cujo canal estabelecia um dos limites da cidade. Era uma área composta em grande parte por mangues, próxima ao porto, e, devido ao esgoto que era despejado in natura, formava um grande brejo insalubre. Após drenagem e aterramento, foi feito ajardinamento do local, dando lugar a uma praça. A partir disso, o Parque Moscoso passou a ser ponto de encontro e convivência dos capixabas com maior poder aquisitivo, como veremos à frente (CANAL FILHO et al, 2012).

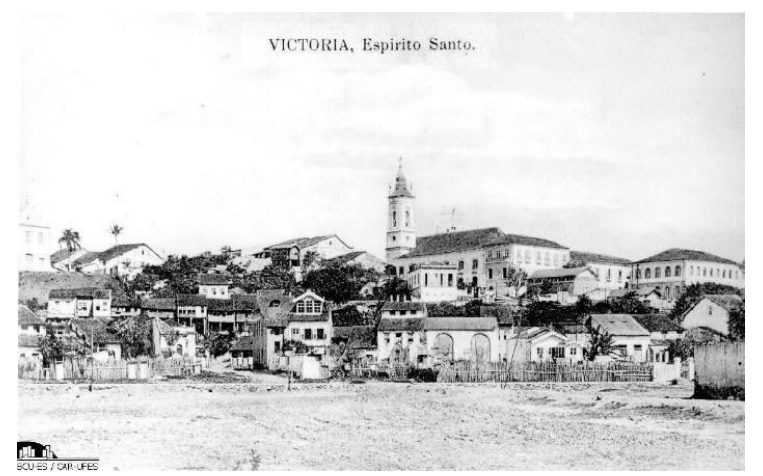

Figura 1 - Parque Moscoso. Rua General Osório, próximo ao atual Centro de Saúde. No alto, a Igreja do São Gonçalo (esquerda) e Palácio do Governo (centro). Autor Desconhecido, 1908

Fonte: BCU-ES/CAR-UFES

O projeto é de autoria do paisagista Paulo Motta Teixeira ${ }^{3}$, que foi contratado para planejar e executar o projeto do parque, dando início às obras em 1910 (Figura 2). Foram dois anos de construção do parque que tem 30 mil $\mathrm{m}^{2}$ de superfície (DIÁRIO DA MANHÃ, 1911a). A

3 Também responsável pelo Horto Municipal e Catedral de Vitória. Desejava criar um jardim botânico (TATAGIBA, 1978). 
obra pelo serviço de ajardinamento custou a quantia de 34:000\$000 (trinta e quatro contos de réis) (LINDENBERG, 1984) ${ }^{4}$.

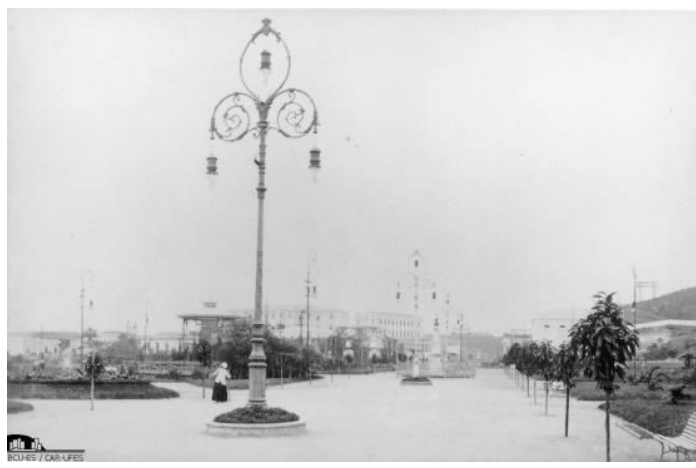

Figura 2 - Alameda do Parque Moscoso, recém inaugurado, em 1912

Fonte: BCU-ES/CAR-UFES

As obras foram iniciadas de acordo com os movimentos artísticos predominantes do século XIX - estilo eclético com traços do $\operatorname{Art}^{-N_{0}}$ veau $^{5}$, inspirado no arquiteto francês Bouvard. Foram incluídos no jardim: fontes luminosas, repuxos, ruínas de templos grecolatinos, caminhos sinuosos e lagoas com ilhotas artificiais com sapos e pontes em concretos, cujos parapeitos imitavam troncos de árvores. Também foram projetados coreto, orquidário e alamedas que dividiam o parque em quatro partes bem definidas (Figuras 3 ).

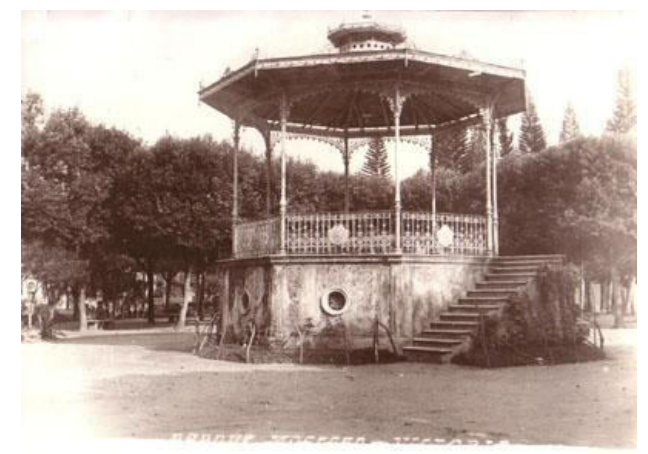

Figura 3 - Coreto, Parque Moscoso, 1931

Fonte: Instituto Jones dos Santos Neves

\footnotetext{
${ }^{4}$ Manteve contrato de conservação do Parque Moscoso, ao mesmo tempo em que cuidava da Praça Oito de Setembro e da Rua Pedro Palácios (TATAGIBA, 1978).

${ }^{5}$ Trata-se de um estilo arquitetônico inspirado nas formas orgânicas da natureza. Caracteriza-se pelo uso de linhas suaves e ondulantes, continuidade dos espaços internos, degradé de tons, uso de ferro e opalina nos elementos arquitetônicos. Na Art-Nouveau predominam motivos de hastes de plantas na ornamentação. Origina-se na Europa, com predomínio entre 1890 e 1905. No Brasil tem influência na arquitetura do início deste século e é considerado frequentemente como um modismo decorativo (ALBERNAZ; LIMA, 1997, p. 76).
}

(c) Urbana: Rev. Eletrônica Cent. Interdiscip. Estud. Cid. Campinas, SP V.9, n.3 [17] 
O Parque Moscoso era aberto ao público, um lugar cercado por uma natureza construída, "paraíso artificial" (MUNIZ, 2001), sendo lugar de passeio das famílias com maior expressão comercial e econômica da cidade, cujas crianças aproveitavam bastante todo cenário ao redor (Figura 4). As mudanças na região, com a construção do Parque Moscoso, repercutiram na vida social da cidade de Vitória, sendo o parque o epicentro de todas essas transformações que foram se sucedendo ao seu redor.

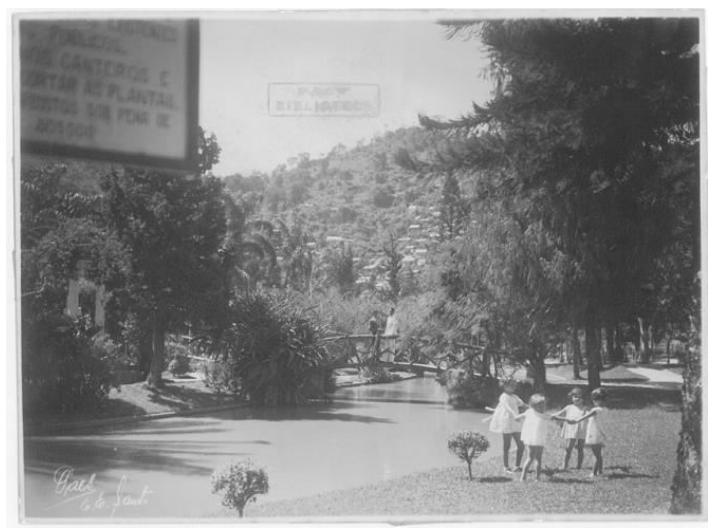

Figura 4 - Centro. Vê-se parte do Parque Moscoso. Ao centro ponte sobre lago.

Grupo de crianças, década de 1930. Photo Paes

Fonte: Arquivo Histórico da Prefeitura Municipal de Vitória

Na década de 1950, durante o governo Jones dos Santos Neves, foi construído o Jardim de Infância Ernestina Pessoa ${ }^{6}$ (Figura 5), no lugar onde era o Parque Tênis Club, frequentado por comerciantes e profissionais para a prática do jogo do tênis. Também foi construída a Concha Acústica (Figura 6), onde eram realizados concertos ao ar livre e outras diversões como show de calouros. Na sua inauguração ocorreram apresentações da Orquestra Sinfônica da Escola Nacional de Música. Ambas as construções são do arquiteto Francisco Bolonha, dentro da arquitetura modernista da década de 1950. Essas obras representam a primeira intervenção no Parque Moscoso (ACHIAMÉ; BETTARELLO; SANCHOTENE, 1991).

\footnotetext{
${ }^{6}$ Foi inaugurado em 1954, na parte norte do Parque Moscoso. Suas salas de aula davam para um jardim interno localizado de frente para o parque. Contém dentro de sua estrutura dois mosaicos vitrificados de autoria de Anísio Medeiros, além da estátua da professora Ernestina Pessoa - uma das primeiras professoras particulares de Vitória, em uma época em que não existiam creches ou escolas infantis. Na década de 1960 eram disputadas as vagas, entre os diferentes níveis sociais, haja vista que o corpo docente era reconhecido por ser um dos mais qualificados de Vitória. Suas dependências estão hoje ocupadas pela Escola da Ciência Física, pertencente ao município de Vitória (CANAL FILHO et al, 2012).
} 


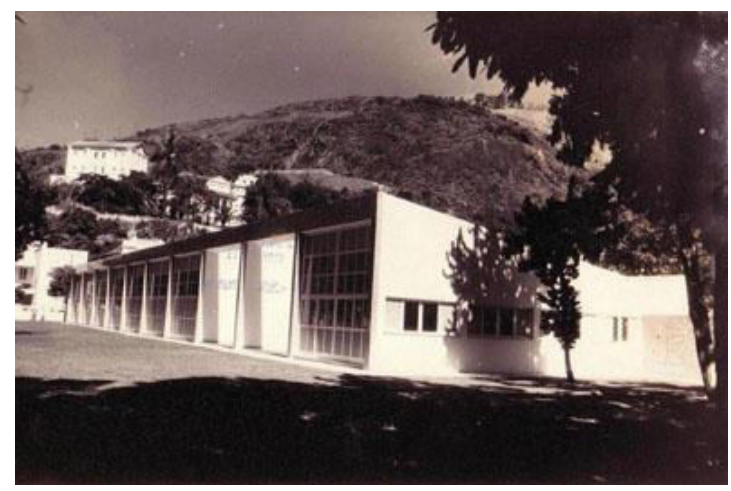

Figura 5 - Vista parcial do Jardim de Infância Ernestina Pessoa, no Parque Moscoso.

Fonte: Instituto Jones dos Santos Neves

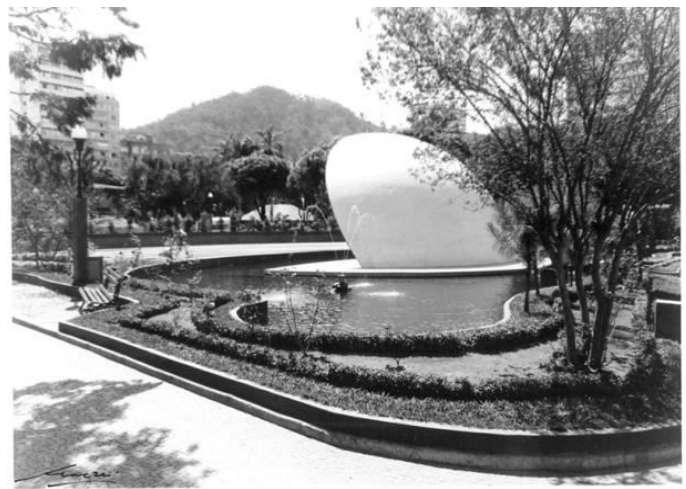

Figura 6 - Parque Moscoso. Vista interna, Concha Acústica. Mazzei, 1970.

Fonte: Arquivo Histórico da Prefeitura Municipal de Vitória

Segundo Campos Junior (2002), o período de prosperidade do Estado durou até a metade da década de 1950, com fortes manifestações na capital. A década de 1960 foi de crise, por conta da desestruturação da produção agrícola, com a erradicação dos cafezais que teve forte impacto no Espírito Santo. Com isso, inicia-se o processo de imigração do campo para a cidade que se estende até a década de 1970.

Em 1973, no governo municipal de Crisógono Teixeira, ocorreram transformações mais drásticas no Parque Moscoso: foram alteradas linhas estruturais e realizadas pequenas construções, mudando não somente sua ambientação, mas também sua função. Alamedas foram desviadas e estreitadas para dar lugar à capela ecumênica, quadra de esportes e instalados brinquedos e equipamentos infantis. Além disso, sua topografia foi alterada, sendo criados alguns morros artificiais (Figura 7). 


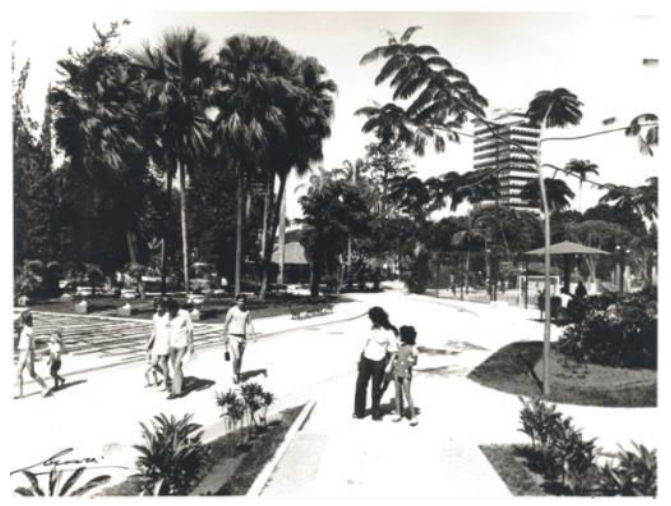

Figura 7 - Parque Moscoso. Vista interna. Mazzei, década de 1970

Fonte: Arquivo Histórico da Prefeitura Municipal de Vitória

Também foram construídos muros com grade e iniciado sistema de cobrança de ingresso, por meio de portais e roletas, diferenciando-se da sua proposta inicial (Figura 8). 0 valor de uso do parque ficou em segundo plano em relação ao seu valor de troca, ou seja, a obra foi substituída pelo produto, com isso, foi se perdendo o verdadeiro sentido de se estar naquele lugar. A cobrança de ingressos reforça a exclusão que acontecia no acesso ao parque. Esse fato nos remete a Lefebvre (1991, p. 117) quando faz uma crítica aos "[...] lazeres comercializados, industrializados, organizados institucionalmente" da cidade.

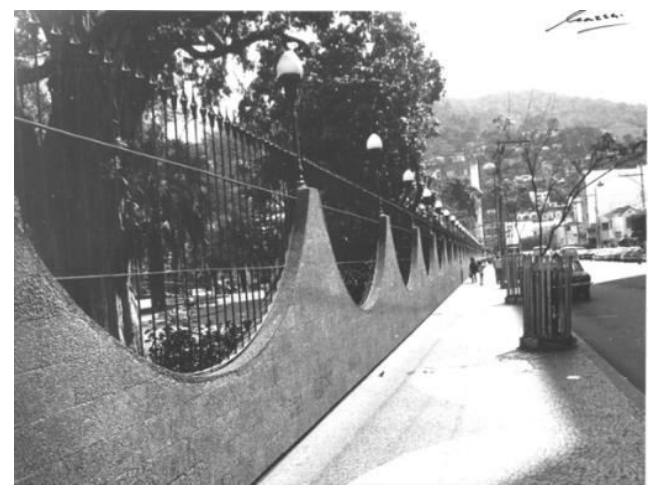

Figura 8 - Parque Moscoso. Mazzei, década de 1970

Fonte: Arquivo Histórico da Prefeitura Municipal de Vitória

Na década de 1980, o Parque Moscoso passou a ter sérios problemas que iniciaram discussões públicas a respeito de seu uso. Nesse período, eram recebidas diariamente aproximadamente três mil pessoas, registrando-se o maior afluxo de pessoas entre 7 e 10 horas, sendo que aos sábados e domingos esse número triplicava, fazendo as cinco roletas do parque girarem até 15 mil vezes. Esse movimento era graças aos brinquedos e ao mini- 
zoológico que atraia frequentadores, principalmente dos bairros periféricos de Vitória em busca de lazer (A GAZETA, 1983) (Figura 9).

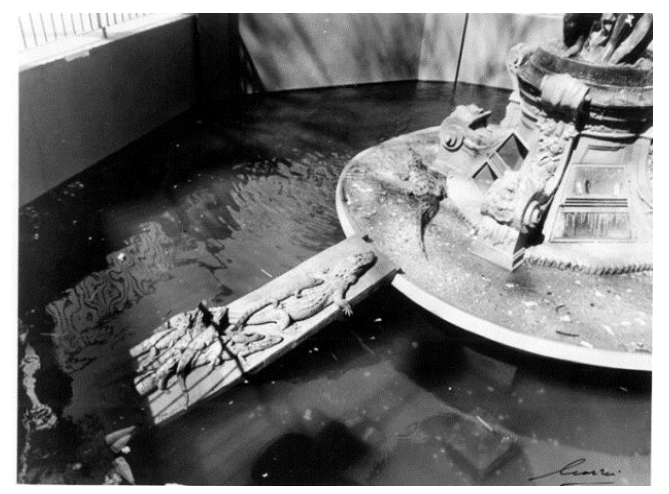

Figura 9 - Parque Moscoso. Tanque dos jacarés.

Fonte: Arquivo Histórico da Prefeitura Municipal de Vitória

Nos anos 2000, existiu um movimento de se recuperar as características originais do Parque Moscoso, no mesmo sentido do projeto de revitalização do Centro de Vitória. No Parque Moscoso, foram recriados os mesmos caminhos, as fontes voltaram às posições originais, e o muro foi substituído por grades. Outras posições e características foram restauradas de modo a se aproximar ao projeto original. O chamado Projeto de Requalificação do Parque possibilitou melhorias na infraestrutura e equipamentos, com o enriquecimento dos jardins, arborização das alamedas e outras intervenções que melhoraram a visualização, inclusive dos monumentos históricos.

Todavia, o entorno do Parque Moscoso não é o mesmo desde sua inauguração em 1912. De lá para cá, ficou evidenciada a progressiva mudança nos usos e nos tipos de edificações que foram se erigindo nas suas mediações. Aquelas antigas residências de luxo foram transformadas em estabelecimentos comerciais e de serviços ou até mesmo demolidas para dar vez a edifícios de usos variados, sobrando ainda alguns exemplos para contar história. Circulam cotidianamente na região centenas de pessoas, de diferentes regiões e classes sociais, desde moradores, servidores públicos, comerciários, frequentadores do próprio parque, sobretudo da terceira idade, vendedores ambulantes, camelôs, turistas até lavadores de carro, moradores de rua, prostitutas e transeuntes em geral.

A partir da apresentação histórica relacionada ao Parque Moscoso e as mudanças urbanas que ocorreram na cidade de Vitória, é possível observar que o parque é um espaço marcado por singularidades que representam um momento histórico importante da história 
capixaba. Como pudemos observar ao levantar material documental e bibliográfico sobre o assunto, não se discute criticamente como e por que esse espaço foi construído e suas implicações políticas e sociais.

Nesse sentido, elaboramos um material educativo que apresenta de modo contrahegemônico o parque, não como um espaço bucólico, como dissemos antes, um "paraíso artificial", mas um local marcado por contradições e interesses de classe. Analisaremos o objeto de nossa pesquisa - o Parque Moscoso - em sua totalidade, buscando contextualizá-lo, respeitando a categoria de historicidade.

Para Siqueira e Ferreira (2015, p. 227):

Apreender a cidade em sua totalidade diz respeito à compreensão do processo que abarca a inserção histórica do homem no seu lugar, uma vez que as cidades agregam à sua constituição - além de pedras e tijolos - significados simbólicos produzidos pela trajetória dos indivíduos que nela habitam.

Assim, como forma de contribuir com as discussões sobre o potencial educativo da cidade, apresentamos a memória constituída no Parque Moscoso por meio de suas fotografias e como essas se relacionam com a constituição da cidade. A partir disso nos perguntamos como o estudo do parque pode favorecer a compreensão das relações entre educação, memória e cidade por meio de um viés contra hegemônico. Na próxima seção apresentaremos a ideia de educação na cidade e como o Parque Moscoso se apresenta como um espaço de educação não-formal potencializador de novas práticas educativas.

\section{Educação na Cidade: o Parque Moscoso como espaço-memória}

Ao estudarmos o Parque Moscoso fazemos um parêntese sobre como ocorreu o processo de modernização da cidade de Vitória. Devido a sua relevância, tomaremos o mesmo como um dos momentos mais importantes desse processo que se inicia no início do século XX. O Parque Moscoso faz parte do cenário da cidade, tendo passado por vários eventos. Suas memórias contam e recontam histórias que dizem respeito não tão somente àquele espaço em si, mas é capaz de recontar a história da nossa cidade.

Lefebvre (1991) defende a ideia de um direito à cidade que de modo geral significa um viver a cidade em sua plenitude, revalorizando os significados existentes na cidade, sobretudo o seu valor de uso, entendendo a mesma diferentemente da cidade como uma mercadoria, como um produto de consumo de acordo com os interesses do capital que acaba 
marginalizando os que detêm menos posses, enquanto na verdade todos sem distinção deveriam ter direito à cidade.

Em diálogo com Gadotti (2006) consideramos que a cidade, além de cumprir suas funções tradicionais (econômica, social, política e de prestação de serviços), exerce também outra função cuja finalidade é a formação para e pela cidade, uma função educativa. Ele propõe uma pedagogia da cidade "[...] para nos ensinar a olhar, a descobrir a cidade, para poder aprender com ela, dela, aprender a conviver com ela" (GADOTTI, 2006, p. 5).

Freire (1993, p. 16) coloca a educação "[...] enquanto processo permanente e a vida das cidades, enquanto contextos que não apenas acolhem a prática educativa, como prática social, mas também constituem, através de suas múltiplas atividades, em contextos educativos em si mesmas". A partir desse ponto de vista é possível promover educação em qualquer espaço da cidade. Dessa forma, "[...] o educador deve contemplar a cidade, pensar a cidade, extrair de cada espaço dela as lições que possam dar mais vida às pessoas, humanizar os cidadãos", como colocado por Sgarbi e Chisté (2016, p. 11).

Dentro disso trabalharemos com a ideia lançada por Freire (1993) de que o conjunto das memórias da cidade também exerce função educativa, pois são manifestações vivas da cultura. O nosso artigo pretende ativar essa memória ligada ao Parque Moscoso em conexão com a cidade, que fala "[...] de épocas diferentes, de apogeu, de decadência, de crises, de força condicionante das condições materiais" (FREIRE, 1993, p. 24).

A partir de Le Goff (1992) é possível pensar que o Parque Moscoso é um lugar de memória. O Parque Moscoso é um espaço físico, um parque urbano na cidade, ao mesmo tempo em que tem conteúdo simbólico, pois representa lembranças de épocas passadas. Le Goff (1992, p. 423) considera "[...] a memória, como propriedade de conservar certas informações, remete-nos em primeiro lugar a um conjunto de funções psíquicas, graças às quais o homem pode atualizar impressões ou informações passadas, ou que ele representa como passadas".

Segundo Lefebvre (1991) a cidade pode apoderar-se das significações políticas, religiosas e filosóficas, o que faz dela um conjunto significante. A cidade existe e tem voz nos edifícios, nos monumentos, e se faz nas ruas e praças, pelos vazios, como também pela teatralização espontânea dos encontros que nelas acontecem, sem contar as festas, as cerimônias, com seus lugares determinados.

Pinto Junior (2012, p. 116) considera que "[...] junto com as novas paisagens arquitetônicas e urbanísticas da cidade, o projeto modernizador acabou renegando

(c) Urbana: Rev. Eletrônica Cent. Interdiscip. Estud. Cid. Campinas, SP V.9, n.3 [17] $\quad$ p.540-571 set./dez. 2017 
determinados aspectos do passado colonial, sobretudo os que faziam referência à cultura popular". Essa modernização foi contraditória em vários aspectos:

[...] pois se por um lado afastava os sujeitos indesejáveis e/ou considerados incapazes de habitar as áreas civilizadas, por outro atraia para as suas cercanias os responsáveis pelo trabalho doméstico diário, pelo transporte de mercadorias, pela construção civil e demais serviços braçais.

Para Lefebvre (1991) o remanejamento da cidade ocorre sempre por uma estratégia de classe que não tem relação com a realidade da cidade, com sua própria vida. Relembra o exemplo de Paris que viveu entre 1848 e Haussmann o auge da vida urbana na capital - vida retratada em poesia e literatura, mas que mais tarde se encerrará. Para ele a vida urbana é permeada por encontros, confrontos, diferenças, conhecimentos e reconhecimentos recíprocos (inclusive no confronto ideológico e político) dos modos de viver que coabitam na cidade.

\section{Fotografias antigas do Parque Moscoso: leitura de imagens}

Antes de mais nada, precisamos compreender o que é a fotografia. Segundo Ciavatta (2007, p. 114) "a fotografia é parte importante da ampliação da capacidade humana de se representar, construindo a história e conferindo significado a essas representações". Mediante essa ideia, para a autora, a fotografia é considerada uma parte da história que se constitui como princípio de memória coletiva que tem ligação com sentimentos, aspirações, interesses, projetos e não são simples fragmento da realidade.

Carnicel (2010, p. 07) ao falar da do caráter polissêmico da imagem fotográfica amplia a definição de fotografia: "[...] fruto de um olhar ingênuo ou crítico, asséptico ou contaminado, a fotografia em seus vários significados pode ser arte, documento, denúncia, relato, verdade, encenação, prova, história... memória". No Brasil se verificou um aumento de pós-graduações, além de livros e periódicos, presentes em muitas áreas interdisciplinares que reúnem antropologia, artes, história, comunicação, arquitetura, e até mesmo psicológica. Esse dado revela os vários campos do conhecimento que deram vez à fotografia como objeto de conhecimento pela sua ampla possibilidade polissêmica (TACCA, 2010).

Nesse quesito, trabalharemos com as fotografias através de uma perspectiva dialógica e polifônica, a partir de Bakhtin (2000) reconhecendo que as fotografias são importantes fontes de conhecimento no ensino, o que permite ao leitor uma compreensão da totalidade social. Para Ciavatta (2007), a totalidade social não diz respeito a um modelo explicativo tão 
somente, mas a um conjunto dinâmico de relações que dizem respeito, necessariamente, à ação dos sujeitos sociais.

O conceito de dialogismo de Bakhtin (2000) possibilitou a compreensão do Parque Moscoso a partir de um percurso que foi possível através das fotografias encontradas basicamente em acervos públicos, como falado anteriormente. Uma série fotográfica que reúne aproximadamente cem fotografias, do início do século XX até os dias atuais, passando por vários períodos da história do Parque Moscoso. A partir disso, analisamos o que essas imagens revelavam sobre os contextos, os processos culturais relacionados e os diálogos com outros enunciados. Então, conforme Macêdo (2016), a leitura não se limita ao conteúdo dos aspectos formais da imagem em si, mas, a possibilidade de ver a obra em diálogo com outras produções, outros textos, outras formas e outras ideias.

O dialogismo dentro da dinâmica da intertextualidade significa a possibilidade de interligar a temática do Parque Moscoso apresentada por meio das fotografias com textos, reportagens, obras de arte, músicas ou poesias com a possibilidade de criar por meio da leitura uma rede de significações. Para Chisté (2015, p. 295):

Essa proposição reforça o fato de que todo texto se constrói como um mosaico de citações, todo texto é a absorção e transformação de um outro texto e, nessa ciranda de significações, o sujeito amplia o seu repertório cultural e sensível e se aproxima cada vez mais do universo do artista.

Chisté (2015, p. 295-296) ainda coloca que esta relação dialógica entre vozes no interior de uma obra de arte está ligada com o conceito de polifonia adotado por Bakhtin (2000).

Com base nessa ideia, é possível pensar que o artista, assim como os leitores, está impregnado por diferentes textos visuais e/ou verbais vistos e lidos que vão compor os seus repertórios criativos. Desse modo, compreendemos que, para que a leitura de uma obra seja realizada de modo aprofundado, é preciso, além dos outros fatores citados, observar os indícios da presença de outras vozes e outros textos (os intertextos) na imagem analisada e, a partir dessas tramas, atribuir sentido a essas conexões. Como se, ao ler, pudéssemos traçar um possível caminho polifônico subjetivo e relativo a cada leitura de imagem realizada e também a cada leitor.

(c) Urbana: Rev. Eletrônica Cent. Interdiscip. Estud. Cid. 
Dentro da perspectiva do dialogismo, Chisté (2015, p. 295) faz uma importante consideração a respeito:

Por conseguinte, interligar a temática do artista com outros textos, como reportagens de revistas, músicas ou poesias para criar, a partir da leitura, uma rede de significações. Essa proposição reforça o fato de que todo texto se constrói como um mosaico de citações, todo texto é a absorção e transformação de um outro texto e, nessa ciranda de significações, o sujeito amplia o seu repertório cultural e sensível e se aproxima cada vez mais do universo do artista.

A importância de se trabalhar com leitura de imagens vem no sentido de desvelar as contradições sociais, ou seja, desnaturalizar certas questões que são colocadas no dia a dia, tomadas como naturais, mas que na verdade não o são, percebendo que as mesmas são resultado de decisões, interesses (particulares e coletivos) e ideologias. Da mesma forma vem o estranhamento ao buscar entender as relações sociais corriqueiras para além da sua aparente normalidade, assumindo uma postura investigativa mediante um mundo aparentemente conhecido e ordinário. Segundo Silva (2010, p. 177):

Vivemos em uma sociedade visual com intensas transformações tecnológicas onde uma avalanche de imagens tem atravessado o espaço social e o mundo do espetáculo exerce uma influência considerável nas relações sociais. Por todos os lugares em que andamos, encontramos imagens que formam sentidos e criam significados. Tal situação pode interferir na naturalização das imagens por parte de professores e alunos. Mas o trabalho com imagens em sala de aula pode ainda se constituir em uma experiência riquíssima de aprendizado, servindo para o questionamento das verdades imagéticas e, portanto, para a sua desnaturalização. As ideias são frutos de uma determinada realidade e nelas estão inseridos elementos que podem formar conceitos ou questioná-los, contribuindo ainda para compreender o contexto no qual foram produzidas.

Para Ciavatta (2009, p. 119) entender a fotografia como mediação:

[...] significa situá-la em sua gênese, conhecer as relações subjacentes ao objeto fotográfico, as razões de ser de determinada imagem, sua trajetória, seus usos e sua apropriação. Significa reconhecê-la como processo social complexo e desvelar sua realidade além da aparência sensível. 
Segundo Ciavatta (2009) ao voltarmos no tempo, por meio das imagens, acabamos por apresentar um certo ponto de vista, algum historicismo que não se mostra apenas como uma argumentação, uma persuasão, um discurso, uma visão de mundo, uma certa concepção de história e de realidade. Nossa visão é por meio da análise de fotografias do Parque Moscoso contribuir para o conhecimento da história local (pouco ou nada contemplada nos livros didáticos) e desvelar as contradições sociais advindas desse processo de modernização de Vitória com foco no que aconteceu no projeto do Parque Moscoso.

A escola torna-se reprodutora de certos modelos que reproduzem concepção da sociedade burguesa sem muitas das vezes tendo noção da influência do capitalismo em seus aspectos econômicos e culturais, o que acaba influenciando as práticas educativa. A própria fotografia desde o seu início foi apropriada pela burguesia, concentrando todo o processo de produção, circulação e consumo de imagens fotográficas até por volta da década de 1950 (MAUAD, 2008).

Segundo Silva (2010, p. 173):

[...] toda e qualquer fonte está sempre imersa em condições sociais de produção e são discursos representacionais do real. As fontes expressam valores políticos, sociais, culturais e religiosos, que devem ser lidos de forma crítica e não como verdades naturais e inquestionáveis.

Mauad (2008) compreende que a imagem visual tem uma capacidade narrativa que diz respeito a uma temporalidade. E a partir disso, estabelece ligações com outras referências culturais de caráter verbal e não-verbal. Isso tem a ver com o dialogismo que segundo Macêdo (2016) pressupõe a ideia de que todo enunciado está em diálogo com enunciados anteriores e posteriores. Dessa maneira, nenhuma obra pode ser vista como um sistema fechado, mas em diálogo, dentro de um processo de comunicação amplo.

Para Ciavatta (2008, p. 38) tomar a fotografia como mediação significa "[...] interpretá-la no conjunto das relações presentes no local e no tempo de sua produção". Nesse sentido, focalizamos de forma complementar, fotografias da cidade de Vitória e do Parque Moscoso, juntamente com fragmentos de reportagens, fotografias de outros espaços, crônicas capixabas e obras de arte, buscando construir um percurso polifônico composto por fontes iconográficas e escritas pertinentes ao tema.

Sobre a fotografia Mauad (2008, p. 26) explica que: 
As fotografias guardam, na superfície sensível, a marca indefectível do passado que as produziu e consumiu. Um dia já foram memória presente, próxima àqueles que as possuíam, as guardavam e colecionavam como relíquias, lembranças ou testemunhos. No processo de constante vir a ser recuperam o seu caráter de presença num novo lugar, num outro contexto e com uma função diferente.

Apresentaremos abaixo uma possível leitura de imagem da memória das paisagens do Parque Moscoso, dentro dessa abordagem que apresentamos logo acima. Nossa ideia é auxiliar o professor a analisar as fotografias antigas do Parque Moscoso de modo a identificar as múltiplas relações intrínsecas que dizem respeito aos aspectos contextuais, formais e outros diálogos existentes entre as imagens lidas e outras produções.

\subsection{Memória das paisagens do Parque Moscoso}

A partir da Figura 10 iniciaremos um diálogo polifônico que promova um passeio entre diferentes referências ligadas ao tema no campo das artes, da literatura, etc. O tema central que queremos discutir através dessa fotografia é a paisagem. Não uma paisagem estática, singular, mas paisagens plurais que vem designar os vários cenários que foram se desenhando no Parque Moscoso, com o passar das décadas ${ }^{7}$.

Enche-se de enthusiasmo quem se aventura a um passeio pela nossa capital tal o fervet opus que se nota por toda a parte. Para o lado de oeste, desde o longiquo bairro de S. Antonio até a praça Moscoso, hoje metamorfoseada n'um dos mais belos parques do Brasil, circumdada de edificações modernas, chics, que dão ao magnífico logradouro um encanto todo novo, ha como que uma febre de melhoramento que entontece, que enleva" (DIÁRIO DA MANHÃ, 1912a, p. 02)

${ }^{7}$ O valor paisagístico não é considerado unicamente (embora também o seja), mas mais considerado em relação com a soma das experimentações das práticas desenvolvidas por um grupo humano nesse lugar. Considerando que a paisagem é uma obra coletiva das sociedades, podemos inferir que a paisagem é também um lugar de memória. 


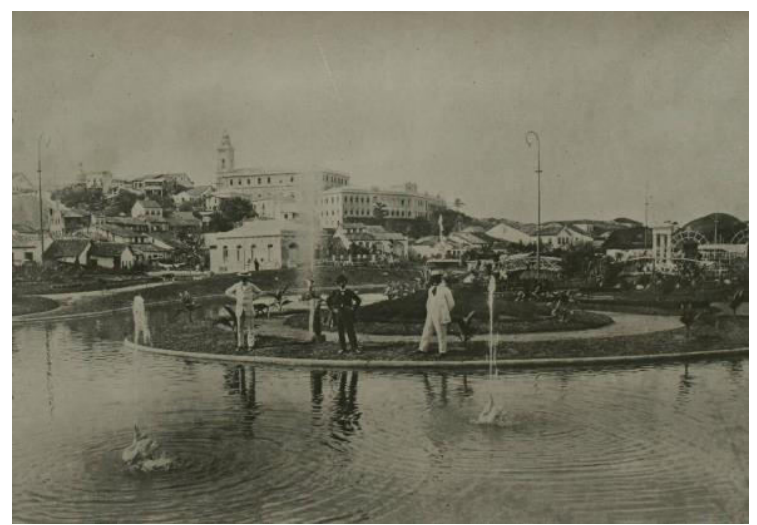

Figura 10 - Inauguração do Parque Moscoso, 1912

Fonte: Arquivo Público do Espírito Santo

Essa passagem citada acima é de um jornal de época que mostra as reformas que ocorriam em Vitória, no início do século XX, tendo o Parque Moscoso como epicentro das transformações urbanísticas que ocorriam pela cidade. A Figura 10 apresenta o Parque Moscoso depois de concluídos os serviços de drenagem, aterro e ajardinamento do local. A fotografia em preto e branco, apresenta uma boa definição, mesmo não sendo a foto original já que faz parte do Relatório de Governo de Jerônimo Monteiro (1908-12). Pode-se inferir que a intenção do fotógrafo era realizar registro imagético que evidenciasse as ações de um governo.

Percebemos por meio dessa fotografia a integração do parque com a cidade, sem muros e prédios ao redor. Nessa época, o Parque Moscoso tinha mais aparência de praça do que parque propriamente dito. A inauguração desse espaço gerou grande repercussão na cidade de Vitória que era carente de logradouros públicos, reunindo ao seu redor a alta sociedade capixaba, conforme aponta o excerto abaixo.

A elegância installou-se lá para os lados do Parque Moscoso. Aquillo ali, aquelle trechosinho tão victoriensemente pacato, é o sangue-azul da cidade, a mais que authetica 'vie dorée' da capital-menina, Victoria-Jean Patou, Victoria-Adrian, espiritual e aristocratica, Victoria que enverga casaca e arrasta, tinha, forçosamente, que escolher para a sua big parade", aquelle recanto. E escolheu mesmo. Não é lá a sede do 'Victoria'? (DIÁRIO DA MANHÃ, 1936, p. 6). 
É possível identificar no centro da fotografia três homens com trajes sociais, sendo o do meio Paulo da Motta Teixeira ${ }^{8}$, paisagista do Parque Moscoso. Verificamos alamedas e caminhos do parque em meio ao lago e gramado. As vegetações utilizadas no projeto são rasteiras com a presença de árvores pequenas. Identificamos pontes, ruínas de colunas que remetem a arquitetura grega, caramanchões, postes de iluminação, lagoa e fontes de água. 0 estilo eclético predomina na concepção do Parque Moscoso, tendo influências da Art Nouveau no projeto original do Parque Moscoso.

O ecletismo tem influência dos manuais europeus, sendo totalmente aberta a modismos estilísticos. A vegetação utilizada, mesma tropical, deve ser organizada com a finalidade de refletir um ideário qualquer, cópia de um modelo ou construção de um espaço bem organizado, diferenciado dos pré-existentes, seguindo regras que constroem cenários muito semelhante com o das metrópoles europeias (MACEDO, 2015).

Já a Art Nouveau por sua vez, foi um estilo decorativo que surgiu entre 1890 e a Primeira Guerra Mundial (1914-18), na maioria dos países da Europa Ocidental e nos Estados Unidos como uma reação contra um historicismo acadêmico presente em grande parte da produção artística do século XIX. Teve como sua maior característica o uso de linhas sinuosas e assimétricas baseadas em formas vegetais. Esse novo estilo apostava na utilização de novos materiais tais como ferro, vidro e cimento (GOMBRICH, 2011).

É possível identificar nos corrimões das pontes e postes de iluminação do Parque Moscoso formas orgânicas da natureza repletas de curvas, volutas e espirais. Essas formas nos remetem à obra de Antonio Gaudí, em especial o estilo utilizado para criar a Casa Batlló, em Barcelona/Espanha, que incorpora elementos da Art Nouveau como formas orgânicas, linhas sinuosas, detalhes decorativos que remetem à flora natural utilizados tanto nas colunas decorativas e no desenho da fachada, quanto na decoração presente no interior do prédio (Figuras 11 e 12).

${ }^{8}$ No projeto introduziu árvores ornamentais, precursor do Horto, pretendia fazer um jardim botânico. Grande desenhista, sendo autor do projeto da catedral e de muitas vilas em Vitória. Faleceu em 1937 (DERENZI, 1995). 


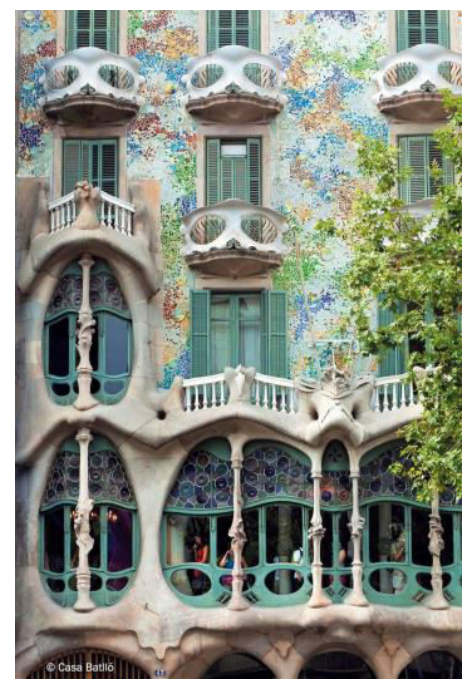

Figura 11 - Fachada da Casa Batlló, Barcelona/Espanha

Fonte: https://www.casabatllo.es/en/gallery/officials/. Acesso: Acesso em:17 ago.2017.

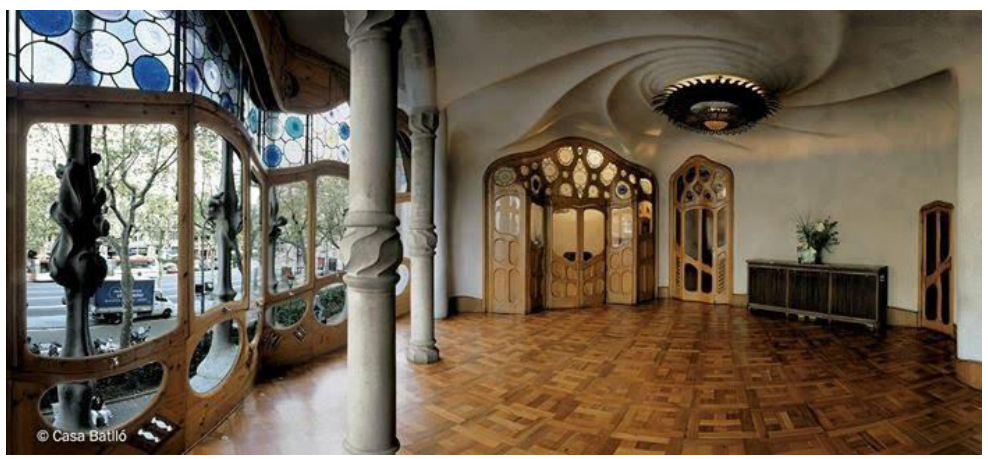

Figura 12 - Interior da Casa Batlló, Barcelona/Espanha

Fonte: https://www.casabatllo.es/en/gallery/officials/. Acesso em:17 ago.2017.

Além da Casa Batlló, obra do arquiteto catalão citado, é possível estabelecer outros diálogos com espaços que dialogam com o projeto arquitetônico e paisagístico do Parque Moscoso e que também foram inspirados na Art Nouveau. A foto de autoria de Marc Ferrez, do Passeio Público do Rio de Janeiro, tirada em 1880, possibilita estabelecer relações entre as pontes presentes nesse espaço carioca e no Parque Moscoso. Se compararmos as Figuras 10 e 13 podemos inferir que existem além dos elementos decorativos que compõe a ponte outro aspecto comum: a preocupação com a criação de pequenos cursos d'água que visam manter a umidade do ar, servir como elemento ornamental, conferindo ao espaço aspecto idílico.

Os cursos de água e as pontes também estão em evidência na Figura 13. A imagem é de autoria de Revert Henrique Klumb, produzida em 1875, e apresenta a família imperial e 
membros do corpo diplomático em frente ao Palácio Imperial, em Petrópolis/Rio de Janeiro. Ao compararmos essas três fotografias (Figuras 10,13 e 14) podemos constatar que existiu uma tendência na época de projetar espaços que proporcionavam a seus visitantes deslocarem-se do tempo/espaço que viviam por meio da vivência diferenciada estabelecida nos espaços artificiais criados na cidade.

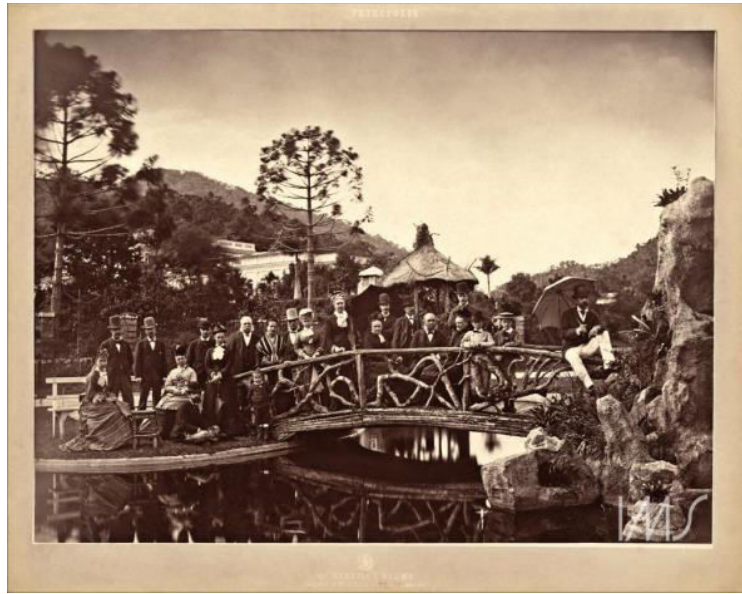

Figura 13 - Família Imperial, 1875

Fonte: Instituto Moreira Salles

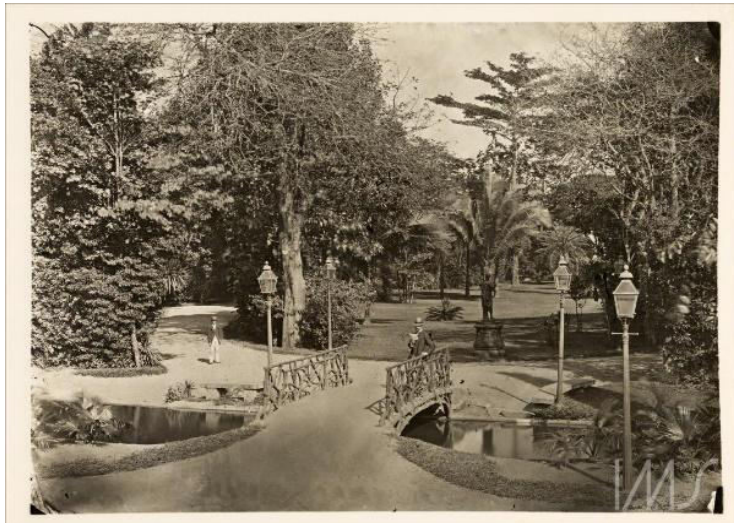

Figura 14 - Passeio Público do Rio de Janeiro, 1880

Fonte: Instituto Moreira Salles

Retomando a imagem principal (Figura 10) que estamos a analisar, outro ponto que se apresenta em relevo refere-se a vista panorâmica que ela destaca. Ao longe podemos 
observar o Palácio Anchieta, na Cidade Alta, onde se iniciou o núcleo original da cidade cercada por casarões coloniais. Por muito tempo essa edificação foi considerada a maior do Espírito Santo. Hoje a região está dominada por edifícios que inviabilizam essa visão para o Palácio Anchieta. Identificamos a imponência desse prédio em relação às outras construções ao redor. Inicialmente o prédio abrigava o Colégio São Thiago, construção jesuítica datada do século XVI. Na fotografia abaixo apresenta-se ainda no seu estado original devido à presença da torre da igreja jesuítica que foi derrubada ainda no governo Jerônimo Monteiro para que o prédio se conformasse definitivamente ao formato de sede de governo. As imagens que seguem nos ajudam a conhecer outro ângulo do Palácio Anchieta no seu estado original e a configuração desse prédio atualmente (Figuras 15 e 16).

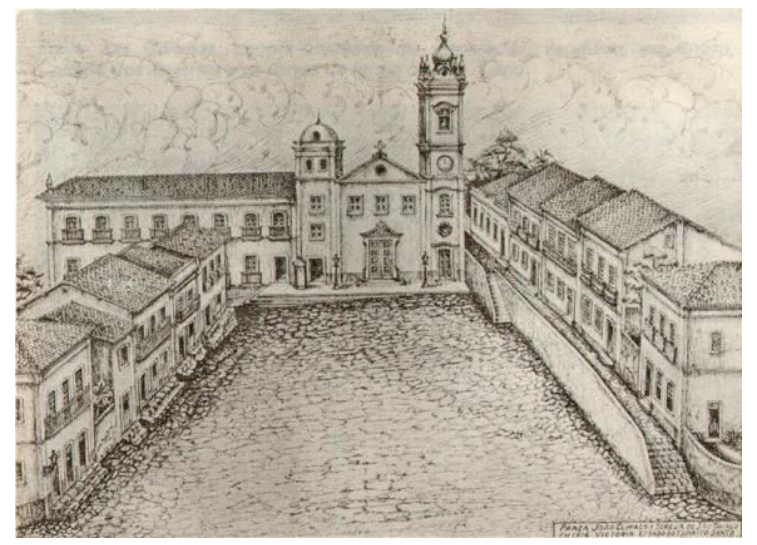

Figura 15 - Vista do Colégio São Tiago na Praça João Clímaco, antigo Largo Afonso Brás ou Praça da Misericórdia. Desenho André Carloni, 1906 Fonte: Memória Visual da Baía de Vitória

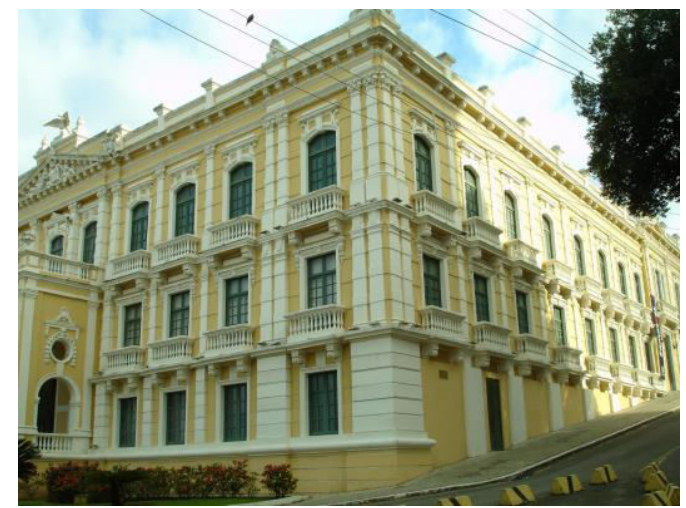

Figura 16 - Fachada atual do Palácio Anchieta, 2017 Fonte: Emannuel Pinheiro 
Outra construção em destaque na imagem é o Colégio Normal Pedro II, construído em meados do século XIX, atualmente Escola Estadual Maria Ortiz (Figura 17) que fica ao lado do Palácio Anchieta. Na vista escolhida pelo fotógrafo é colocado em destaque o fundo dessa construção.

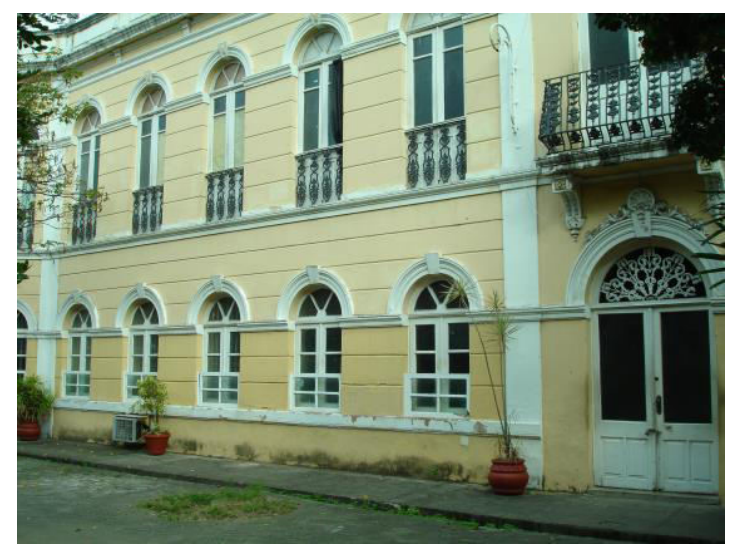

Figura 17 - Escola Estadual Maria Ortiz, 2017

Fonte: Emannuel Pinheiro

Além dos destaques apresentados notamos, através da Figura 10, que nas imediações do Parque Moscoso existiam casas de aspecto mais simples, principalmente ao lado esquerdo da imagem. Essa nova paisagem que se criava estava em contraposição ao que era o local antes, como mostra essa passagem do jornal da época: "E Jeronymo Monteiro trabalhou. [...] como também a elle deve o aterramento do Campinho, que é hoje uma praça belíssima e imensa em vez de um asqueroso lamarão fétido e doentio [...]" (DIÁRIO DA MANHÃ, 1912b, p. 02). Possivelmente essas casas mais simples já existiam antes da criação do Parque Moscoso e virão a desaparecer posteriormente com a construção de casas de maior padrão.

Duas décadas mais tarde percebemos que a vegetação do Parque Moscoso cresceu (Figura 18). A fotografia em preto e branco apresenta uma visão mais ampla do cenário do Parque Moscoso, apresentando outro ponto de vista do local que revela ao fundo um morro que faz parte do Maciço Central ${ }^{9}$, já ocupado em sua base por moradias. Trata-se de uma imagem que exalta o paisagismo, evidenciando a harmonia e a organização dos elementos. Como dissemos, o Parque Moscoso era formado por uma natureza idílica, um locus amoenus, um local aprazível, como narrado nos jornais da época.

${ }^{9}$ Área de Preservação Permanente (APP) de Vitória.

(c) Urbana: Rev. Eletrônica Cent. Interdiscip. Estud. Cid. 




Figura 18 - Vista parcial do Parque Moscoso, 1932?, autor desconhecido Fonte: Instituto Jones dos Santos Neves

O parque foi artisticamente construído e se tratava de um lugar poético ou, dito de outro modo, um espaço romântico. Chamado também de "jardim dos namorados" (VIDA CAPICHABA, 1935, p. 10), "recanto esquecido do paraiso" ou "jardim dos nossos antepassados" (VIDA CAPICHABA, 1932, p. 15). A fotografia acima (Figura 18) reforça todos os adjetivos dados ao parque, pois trata-se da criação de um projeto que em seu fim conseguiu criar um espaço diferenciado para a cidade de Vitória. A lagoa tem grande presença na fotografia, onde também é possível verificar uma fonte à esquerda, junto do conjunto de vegetação formado por plantas e árvores abundantes.

O Eden, o Paraiso da Victoria! Vós que me ledes talvez achaes singular que afirme ter a nossa capital o jardim das delicias do qual foram expulsos os paes da humanidade pela transgressão, pelo pecado original. De facto, agora o não tempos, mas em breve... E se me não querei dar crédito 'só terdes a bondade de acompanhar-me até ali, ao Campinho, á Villa Moscoso, e então haveis de ver que não sou um embusteiro, um contador de rodellas (DIÁRIO DA MANHÃ, 1911b, p. 02).

Pinheiros, ciprestes entre outras plantas exóticas foram plantadas no Parque Moscoso, como forma de se aproximar dos jardins de países de clima temperado. Também fazia referências à cultura grega, inclusive a instalação de ruínas, lembrando em muitos trechos a paisagem da região da Arcádia. Argan (2014, p. 213) coloca que antigamente e não muito tempo atrás, a região do mito e do sagrado era a natureza. Completa dizendo que a natureza era o que se encontrava "[...] fora dos muros da cidade, o espaço não protegido, não 
organizado, não construído". A natureza presente no Parque Moscoso estava representada por uma Arcádia cultivada e não uma Arcádia primitiva (SCHAMA, 1996), o que identificamos ao analisar na Figura 19.

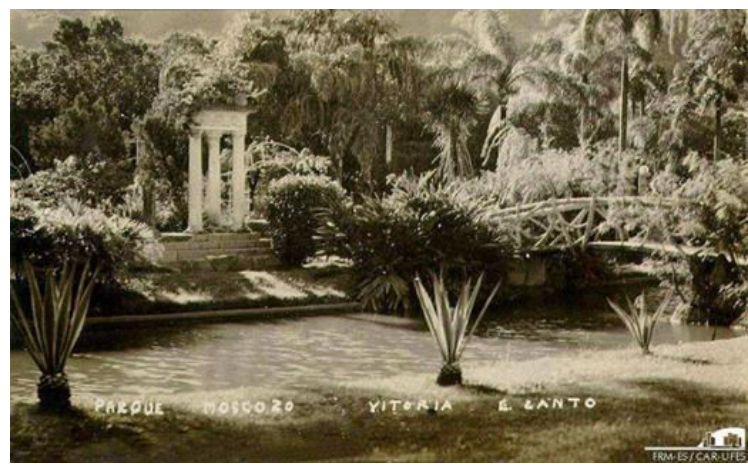

Figura 19 - Jardins do Parque Moscoso, 1940

Fonte: FRM-ES/CAR-UFES

Em relação às áreas verdes, projetava-se uma ideia de natureza medida e controlada, a partir da concepção do paisagismo, como nos jardins europeus copiados.

Por falar em Moscoso, eu tenho o meu fraco pela natureza, sou um grande admirador do Moscoso. Atualmente está adoravel: a sonolência de suas aguas; o matiz de suas flores; a coluna da ilha dos amores, triste e mutilada qual Venus de Milo; as alamedas perfiladas como em homenagem ás Deusa que ali transitam; o frêmito das palmeiras aos ósculos da viração; galhos que se entrelaçam ao açoite do vento como namorados que se abraçam ao açoite do amor; parsinho de noivos discretos lá no banquinho, distante da turba... Quanta poesia! (REVISTA VIDA CAPICHABA, 1933, p. 08).

Na década de 1950 foram construídos o Jardim de Infância Ernestina Pessoa e a Concha Acústica, projetadas por Francisco Bolonha. Ambas construções são exemplos significativos da arquitetura moderna brasileira. A Figura 20 apresenta uma vista panorâmica, possivelmente tomada do alto de um edifício, onde é possível ter uma visão geral do Parque Moscoso com suas novas características, com destaque para a Concha Acústica onde são realizados espetáculos para um grande público ao ar livre. 


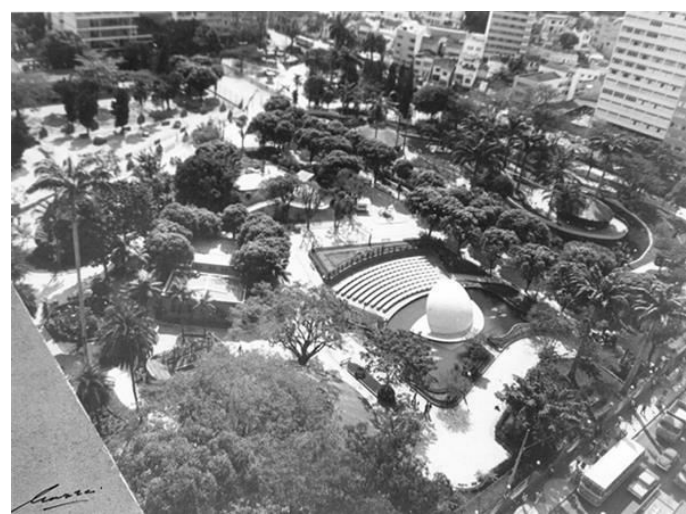

Fig. 20 - Vista geral do Parque Moscoso. Autoria: Mazzei. Década de 1970

Fonte: Arquivo Público Municipal de Vitória

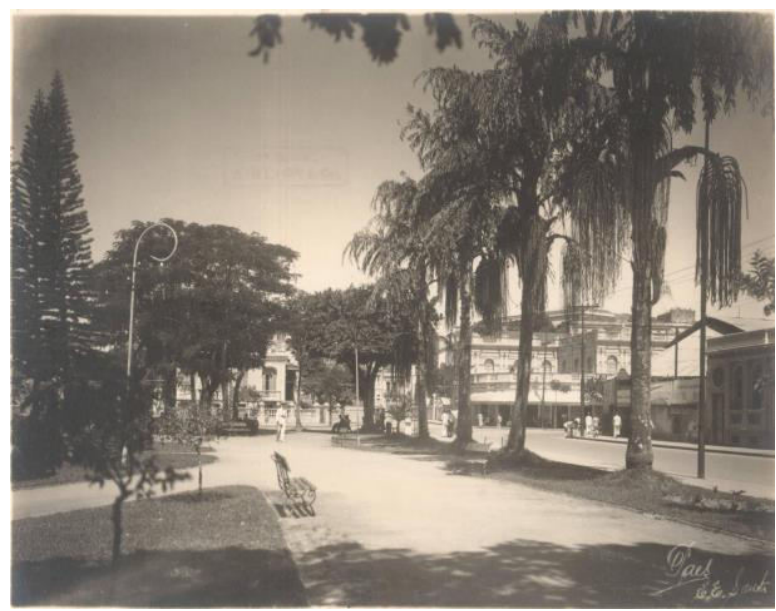

Figura 21 -Parque Moscoso. Photo Paes, 1936

Fonte: IJSN-ES/CAR-UFES

Como falado anteriormente, não existia muro ao redor do Parque Moscoso, como identificamos na Figura 21. Na década de 1970, por questões de segurança, o Parque Moscoso foi murado e gradeado, limitando sua utilização e modificando sua função inicial de local de passeio, descanso ou mesmo de passagem entre as ruas próximas. Um sistema de cobrança de ingressos com instalação de portarias e roletas foi instalada.

A Figura 22 apresenta o parque murado. Sobre essa transformação do Parque Moscoso a escritora capixaba Marzia Figueira ${ }^{10}$ (1994, p. 47) escreve:

10 Nascida em Vitória (ES). Formada em História na Universidade Federal do Espírito Santo (UFES). Jornalista de A Gazeta. Cronista e membro da Academia Espírito-Santense Feminina de Letras.

(c) Urbana: Rev. Eletrônica Cent. Interdiscip. Estud. Cid. Campinas, SP V.9, n.3 [17] 


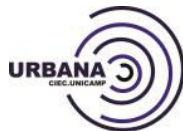

DOI: $10.20396 /$ urbana.v9i3.8650213

O bonde passava ao redor, moroso, talvez para não perturbar o silêncio que no Parque se desfrutava. À sombra do qual se formavam pares, se namorava nos bancos - em sossego e paz. O ambiente era propício, além de convidativo e acolhedor. Por isso, as famílias também se reuniam por ali, não apenas as crianças e os namorados, os poetas e... os fotógrafos. Sim, porque como todo parque dos anos 50 o Moscoso também tinha seus lambe-lambe, de saudosa presença nos retratos amarelecidos pelo tempo... Depois, a cidade foi se modificando, o Clube Vitória trocou de lugar, perdeu o encanto - e os sócios. O Parque Moscoso ficou perigoso, foi cercado, trancado, patrulhado. A entrada deixou de ser franca - e risonha. Agora se paga ingresso, se impõem limites, se ditam regras, e proibições. Não tem mais bonde passando por lá, em direção à praça do Quartel. Aliás, não tem mais praça e nem Quartel. O Salesiano se mudou, foi para o Forte São João. Prédios se ergueram em volta, sufocando o verde, roubando o ar puro, emparedando o Parque em nome da ordem e do progresso.

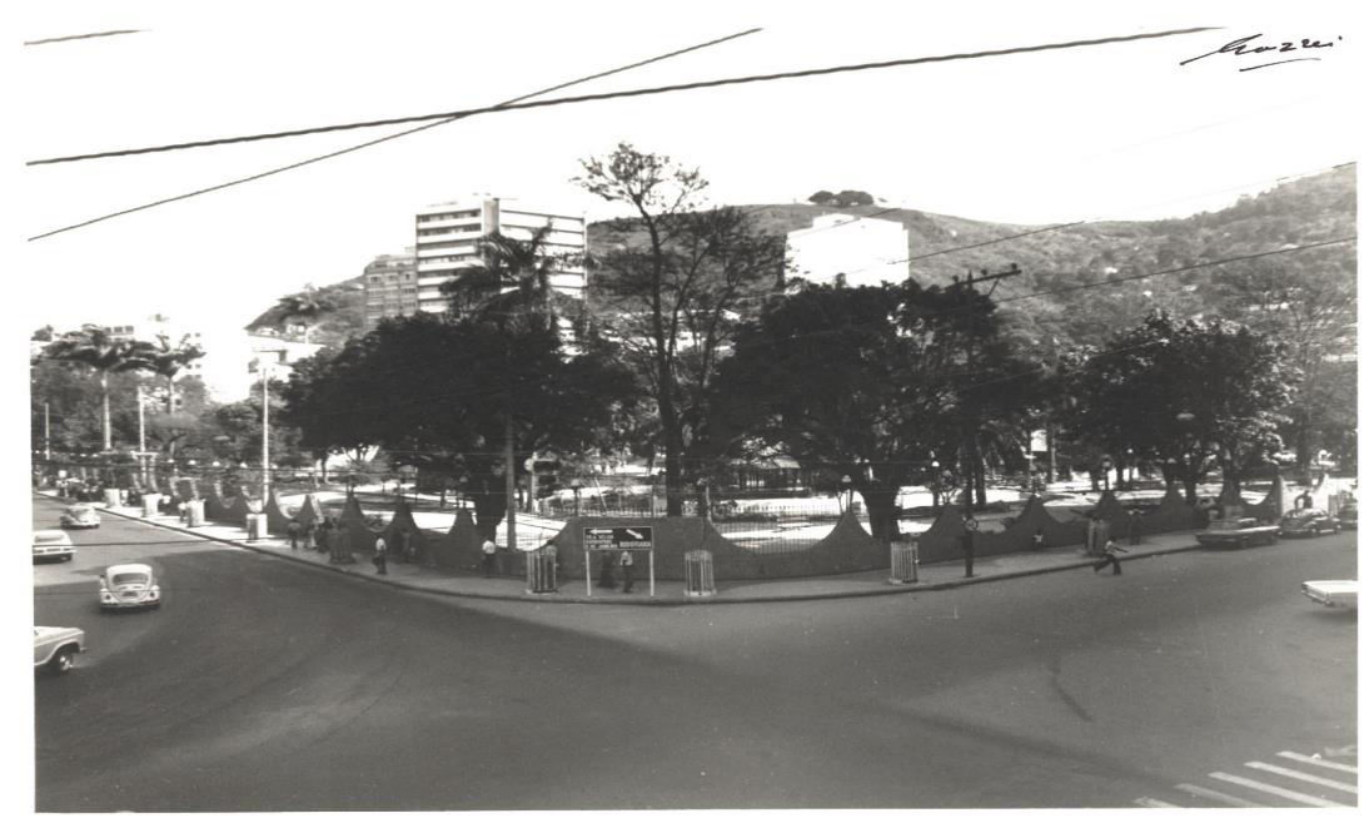

Figura 22 - Vista parcial do Parque Moscoso. Autoria: Mazzei, década de 1970 Fonte: Arquivo Público Municipal de Vitória

Na Figura 22 também observamos o início do processo de verticalização da cidade de Vitória com o aparecimento de alguns edifícios ao redor do Parque Moscoso, o que veio a 
substituir os casarões construídos no início do século XX. Na década de 1970 as linhas estruturais do parque foram alteradas e pequenas construções acrescentadas, mudando a ambientação e a função do mesmo. As alamedas foram desviadas, tornadas mais estreitas, dando lugar às quadras de esporte, à capela ecumênica e brinquedos industrializados de playgrounds para as crianças, modificando ainda mais o seu primeiro uso. O parque antes totalmente plano teve sua topografia alterada com a criação de morros artificiais em alguns canteiros (Figura 23).

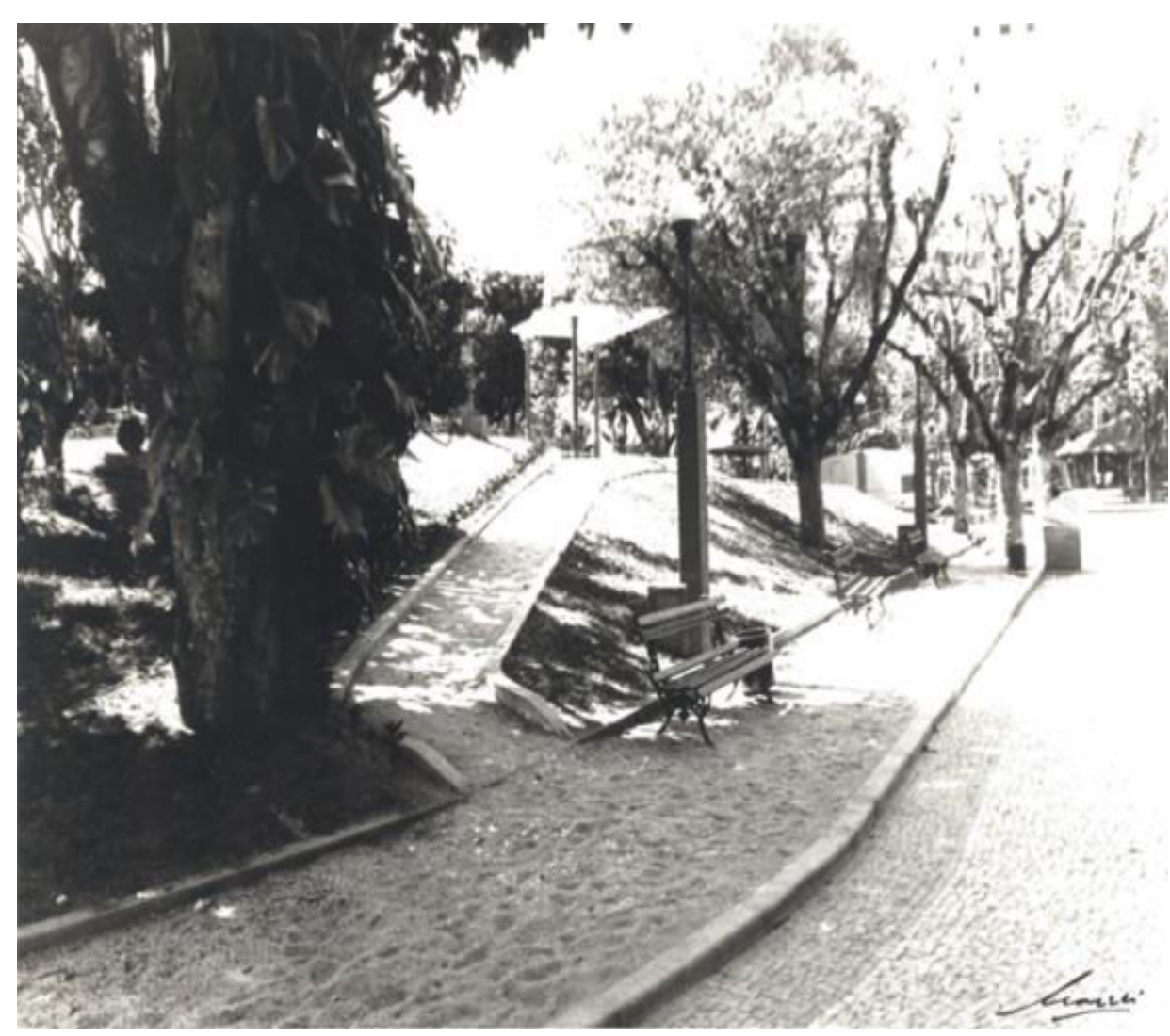

Figura 23 - Vista interna do Parque Moscoso. Autoria: Mazzei, década de 1970 Fonte: Arquivo Público Municipal de Vitória

A autora Maria Helena Hees Alves ${ }^{11}$ (1994, p. 41) apresenta essa nova configuração espacial, inclusive, os animais que começaram a fazer parte do cenário do Parque Moscoso:

11 Nascida em Vitória (ES). Formada em Biblioteconomia (UFES). Escritora. Membro da Academia Espírito-Santense Feminina de Letras. Autora de O Manto do Rei (1986), Circo do Mico (1986), TrocaTroca no Reino dos Bichos (1990) e A Venda do Senhor Vento (1990).

(c) Urbana: Rev. Eletrônica Cent. Interdiscip. Estud. Cid. Campinas, SP V.9, n.3 [17] 
Lá fora, além das grades, o burburinho e o calor de uma tarde de verão. Passo pelo quiosque dos macacos, pelo viveiro dos pássaros e vou indo, caminhando sem pressa. Paro diante de um jacaré estendido sobre uma pedra. [...] Tive esperanças de encontrar alguém que me inspirasse uma relação mais profunda com o Parque. Para isso continuei minha caminhada. Subi e desci morrinhos, passei por pontes e lagos e acabei sentada num banco à sombra de uma árvore. A meu lado um homem grisalho lia um livro. Tão alheio e absorto que nem deu pela minha presença. É esse que há de me dizer alguma coisa, pensei. Quem sabe perguntar logo e deixar de lado essa de advinhar o que diriam as pessoas que ali estavam naquela quarta-feira ensolarada?

A Figura 24 representa esse momento de transformação do Parque Moscoso, onde a presença dos animais era uma grande atração para o público que comparecia no Parque Moscoso. Macacos, patos, veados, antas, faisões, jabutis, pavões, gansos e até jacarés faziam parte do espaço do Parque Moscoso.

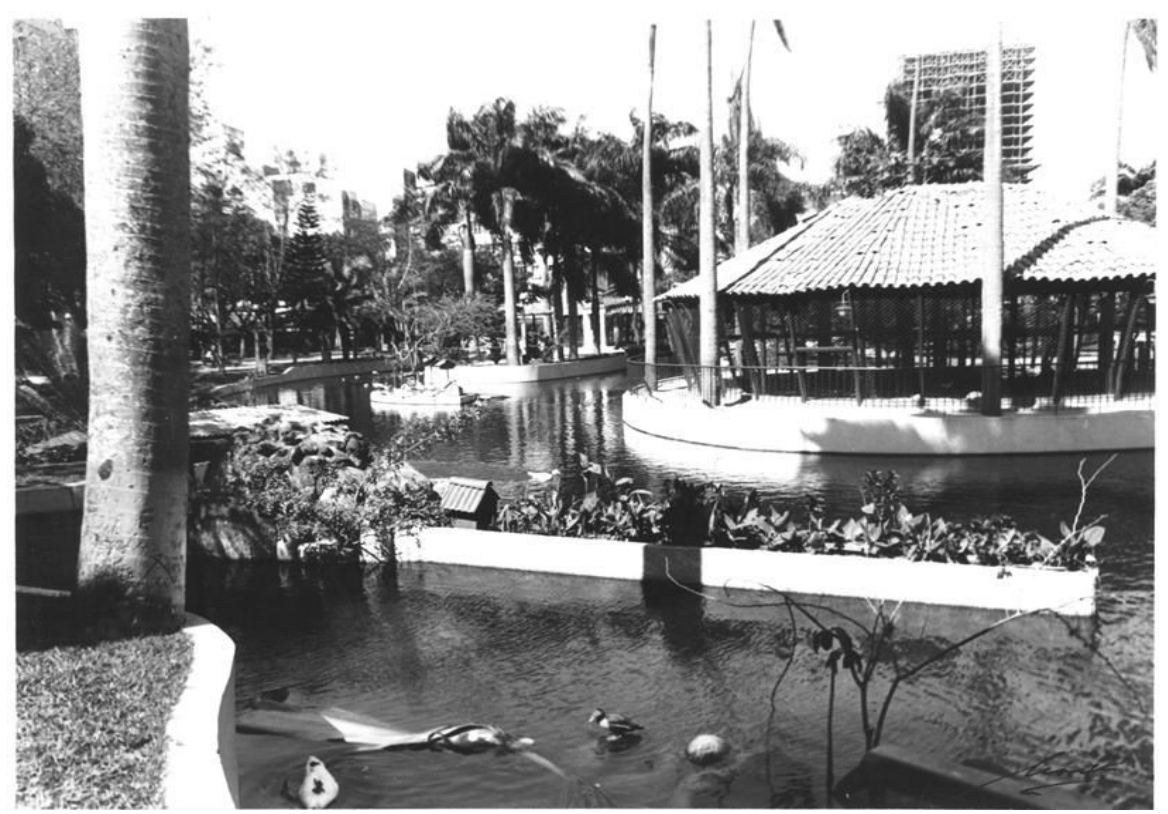

Figura 24 - Vista interna do Parque Moscoso. Autoria: Mazzei, década de 1970 Fonte: Arquivo Público Municipal de Vitória

O Parque Moscoso passou por novas transformações, nos anos 2000, tentando voltar a sua ambiência da sua inauguração, na tentativa de se recriar espaços bucólicos, de apreciação da natureza e lazer contemplativo (Figura 25). 


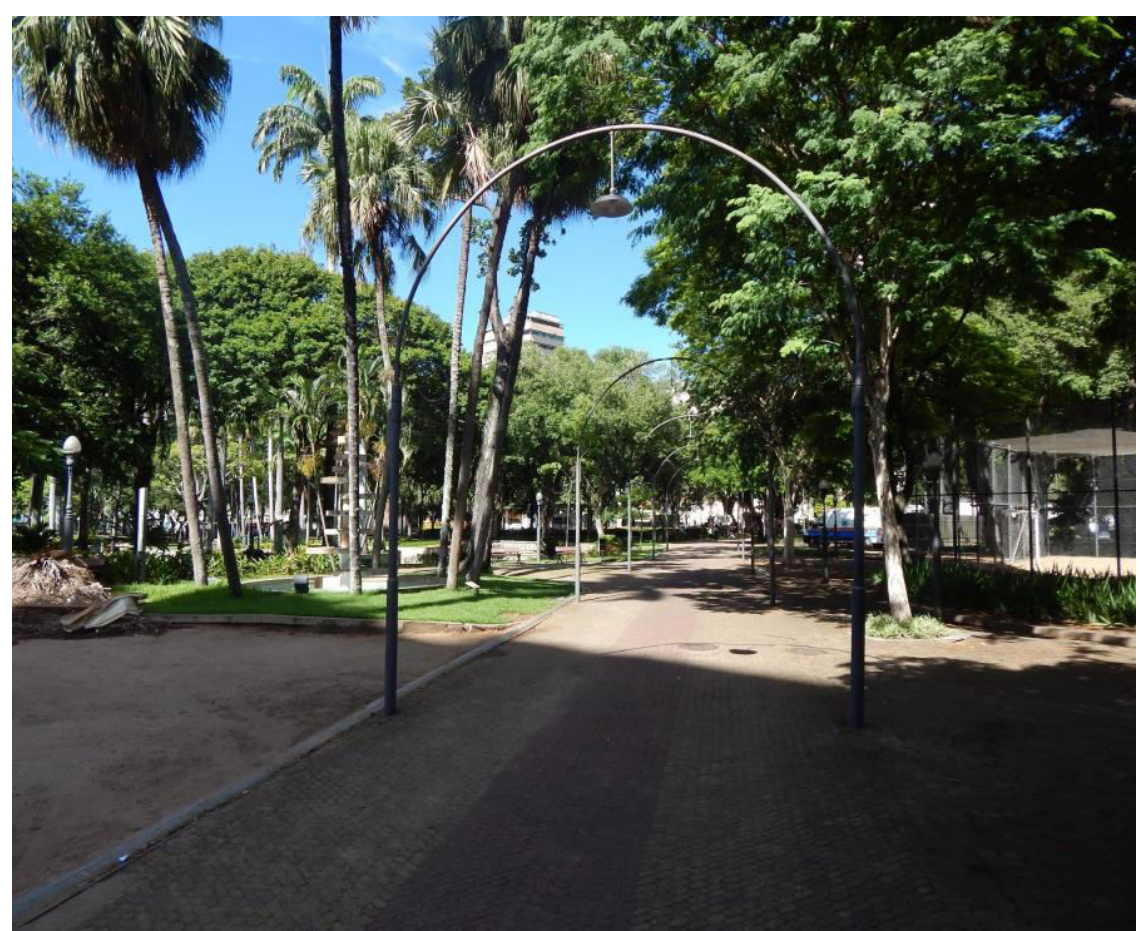

Figura 25 - Alameda central do Parque Moscoso, 2017

Fonte: Emannuel Pinheiro

Por meio desse exercício tentamos aplicar os diversos conceitos citados, em especial os que promovem o diálogo entre as imagens e outros textos históricos, artísticos, sociais, comunicacionais etc., resultando na composição de repertórios criativos que possibilitaram uma leitura que remontou o processo de urbanização da cidade de Vitória, tendo como foco as transformações ocorridas no Parque Moscoso nos seus vários momentos, de sua origem até chegar aos dias atuais. Esperamos que cada leitor deste material educativo também possa estabelecer novas relações entre as imagens, criando diferentes percursos de leitura crítica e revelando processos criativos e de produção de sentidos relacionados ao desvelamento do processo de modernização da cidade de Vitória.

\section{Considerações Finais}

O Parque Moscoso é um parque urbano que foi construído no início de século passado, na cidade de Vitória, dentro de um ideário capitalista de urbanização em sintonia com outras cidades brasileiras, como o Rio de Janeiro que serviu de exemplo para todo o país. O que aparentava ser somente um projeto de urbanização de uma área que apresentava sérios problemas de saneamento tratou-se na verdade de uma reforma para atender interesses capitalistas de uma classe detentora de poder econômico e político. 
Muitos acontecimentos aconteceram no Parque Moscoso no percurso de sua história, sendo sua memória remontada de várias formas, dentre elas, imagens contidas em fotografias. Abordamos o Parque Moscoso dentro da perspectiva da educação na cidade, compreendendo que a vivência na cidade por si só é um espaço cultural de aprendizagem. Dessa forma, "[...] o educador deve contemplar a cidade, pensar a cidade, extrair de cada espaço dela as lições que possam dar mais vida às pessoas, humanizar os cidadãos", como colocado por Chisté e Sgarbi (2016, p. 11).

Trabalhar com memória no Parque Moscoso é evitar que se perca algumas de muitas histórias possíveis da cidade. Dentro de uma relação dialética, a sociedade produz o espaço e o espaço produz a sociedade. O Parque Moscoso não é resultado do trabalho humano somente, mas o processo de trabalho (de fazer-se humano engendrado por conflitos sociais) que levou a construção desse espaço. O Parque Moscoso não é um projeto terminado. Ainda é um espaço em aberto, em constante construção, o que possibilita sua transformação a partir da tomada de consciência das atuais condições.

Trabalhamos com leitura de imagens de fotografias numa perspectiva dialógica e polifônica de modo a representarem aspectos ligados à memória do Parque Moscoso. Nossa pesquisa busca ampliar as práticas pedagógicas, apresentando novos espaços com potenciais educativos dentro da nossa cidade. Também se espera que seja um trabalho realizado de forma colaborativa e que questione a realidade educativa na busca de novas proposições que sejam reverberadas em sala de aula.

Para que isso seja possível, propomos trabalhar com fotografias antigas do Parque Moscoso buscando desvelar contradições, compreender o parque como uma totalidade, mostrando que novos espaços de sociabilidade como no caso do Parque Moscoso não foi apropriado por toda população, aprofundando a segregação socioespacial de uma cidade marcada por uma modernização excludente.

Constatamos que possibilitar experiências educativas sobre este tema são importantes para valorizarmos espaços das nossas cidades ampliando as possibilidades do fazer pedagógico. A cidade de Vitória conta com uma rica história, presente no seu espaço urbano: ruas, avenidas, prédios, praças, parques, edifícios, etc. com grande potencial de ser explorado em sala de aula, e, principalmente fora dela, o que tornaria o trabalho educativo ainda mais completo.

(c) Urbana: Rev. Eletrônica Cent. Interdiscip. Estud. Cid. Campinas, SP V.9, n.3 [17] p.540-571 set./dez. 2017 


\section{Referências}

A GAZETA. Parque Moscoso: os problemas da única área de lazer de Vitória. A Gazeta, Vitória, ES, 07 ago. 1983, Cad. 2, c. 1-5.

ACHIAMÉ, Fernando Antônio de Moraes; BETTARELLO, Fernando Augusto de Barros; SANCHOTENE, Fernando Lima (Orgs). Catálogo de bens culturais tombados no Espírito Santo. São Paulo-Vitória: Massao Ohno Editor/Secretaria de Estado de Educação e Cultura/Conselho Estadual de Cultura/Universidade Federal do Espírito Santo, 1991.

ARGAN, Giulio Carlo. História da arte como história da cidade. São Paulo: Martins Fontes, 2005.

ART-nOUVeaU. In: ALbernaz, Maria Paula de; LIMA, Cecília Modesto. Dicionário Ilustrado de Arquitetura. São Paulo: ProEditores, 1997, p. 76, Volume 01.

BAKHTIN, Mikhail. Estética da criação verbal. São Paulo: Martins Fontes, 2000.

CHISTÉ, Priscila de Souza. Leitura lenta da obra de arte como proposta para educação estética: contribuições de Marx e Vigotski. Revista Reflexão e Ação, Santa Cruz do Sul, v. 23, n.1, p. 276-302, jan./jun. 2015.

CHISTÉ, Priscila de Souza. Momentos pedagógicos da pedagogia histórico crítica. Vitória, 2016. No prelo.

CAMPOS JUNIOR, Carlos Teixeira de. A construção da cidade: formas de produção imobiliária em Vitória. Vitória: Floricultura, 2002.

CANAL FILHO ET AL, Pedro (Org.). Parque Moscoso. Vitória: Instituto Goia, 2012.

CARNICEL, Amarildo. Em novo suporte de memória. Resgate, vol. XVIII, nº19, jan/jul, 2010, p. 07-08.

CIAVATTA, Maria. Mediações históricas de trabalho e educação: gênese e disputas na formação dos trabalhadores (Rio de Janeiro, 1930-60). Lamparina: Rio de Janeiro, 2009.

(c) Urbana: Rev. Eletrônica Cent. Interdiscip. Estud. Cid. Campinas, SP V.9, n.3 [17] $\quad$ p.540-571 set./dez. 2017 
CIAVATTA, Maria. Memória e temporalidades do trabalho e da educação. Lamparina: Rio de Janeiro, 2007.

DIÁRIO DA MANHÃ. Actos officiaes. Diário da Manhã, Victoria, Estado do E. Santo, 4 mar. 1912a, Anno VII, Num. 63, p. 02.

DIÁRIO DA MANHÃ. Ainda a successão presidencial. Diário da Manhã, Vitória, Espírito Santo, 1912 b, p. 02.

DERENZI, Luiz Serafim. Biografia de uma ilha. Vitória: PMV, Secretaria Municipal de Cultura e Turismo, 1995[1965].

FREIRE, Paulo. Educação permanente e as cidades educativas. São Paulo, Vila das Letras, 1993.

GADOTTI, Moacir. A escola na cidade que educa. Cadernos Cenpec: educação e cidade, 2006, n. 1, p. 133-139. Disponível em: <file://D:/Documentos/Downloads/caderno-cenpec-1.pdf>. Acesso em: 10 jun. 2016.

GOMBRICH, Ernst Hans. A história da arte. Rio de Janeiro: LTC, 2011.

LE GOFF, Jacques. História e Memória. Campinas: Unicamp, 1992.

LEFEBVRE, Henri. O direito à cidade. São Paulo: Moraes, 1991.

LINDENBERG, Maria Alice. O parque Moscoso está de roupa nova. A Gazeta, Vitória, ES, 30 jan. 1984 , p. 01 , Cad. 2, c. 1-5.

MACÊDO, Érika Sabino de. Pelos muros da cidade: uma leitura de imagem do Grafitti de Vitória. Vitória: FAPES, 2016.

MACEDO, Silvio Soares. Quadro do paisagismo no Brasil 1783-2000. São Paulo: Editora da Universidade de São Paulo, 2015. 
MAUAD, Ana Maria. Fotografia e História: possibilidades de análise. In: CIAVATTA, Maria; ALVES, Nilda (Orgs). A leitura de imagens na pesquisa social: história, comunicação e educação. São Paulo: Cortez, 2008.

MUNIZ, Maria Izabel Perini. Parque Moscoso: documento de vida. Vitória: IHGES, 2001.

PINTO JUNIOR, Arnaldo. Modernização urbana e educação das sensibilidades na cidade de Vitória (1890-1912). Resgate, vol. XX, n023 - jan/jun., 2012, p. 108-118.

REVISTA VIDA CAPICHABA. Alfinetadas, Vitória, Espírito Santo, 1932, p. 15.

REVISTA VIDA CAPICHABA. Carta aberta. Revista Vida Capichaba, Vitória, Espírito Santo, 1933, p. 08.

REVISTA VIDA CAPICHABA. Alfinetadas. Revista Vida Capichaba, Vitória, Espírito Santo, 1935, p. 10.

RODRIGUEZ, Margarita Victoria. Pesquisa social: contribuições do método materialista histórico-dialético. In: CUNHA, Célio da; SOUZA, José Vieira de; SILVA, Maria Abádia. 0 método dialético na pesquisa em educação. São Paulo: Autores Associados, 2014.

SCHAMA, Simon. Paisagem e Memória. São Paulo: Companhia das Letras, 1996.

SGARBI, Antonio Donizetti; CHISTÉ, Priscila de Souza. Cidade educativa: reflexões sobre educação, cidadania, escola e formação humana. Revista Debates em Educação Científica e Tecnológica, Vitória, v. 6, n. 1, out. 2015.

SIQUEIRA, Maria da Penha Smarzaro; FERREIRA, Gilton Luís. O lugar da opinião. A cidade e os espaços de produção social da opinião pública. Cad. Metrop. São Paulo, v. 17, n. 33, pp. 225242, maio 2015.

SILVA, Edlene Oliveira. Relações entre imagens e textos no ensino de História. sÆEculum Revista de História [22]; João Pessoa, jan./ jun. 2010. 
SOUSA, Everaldo Simões. Espaço de memórias coletivas. A Gazeta, Vitória, ES, 19 mai. 2012, Cad. Pensar, p. 6-7.

TACCA, Fernando de. Fotografia e memória. Resgate, vol. XVIII, n 19, jan/jul, 2010, p. 0910.

TATAGIBA, Fernando. Parque Moscoso: 67 anos (I): no início, o lugar mais bonito. A Tribuna, Vitória, ES, 12 fev. 1978. 